\title{
Ecosystem management in paludified boreal forests: enhancing wood production, biodiversity, and carbon sequestration at the landscape level
}

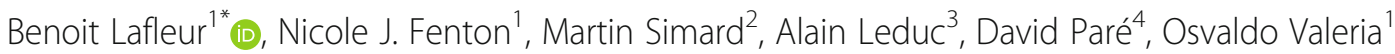
and Yves Bergeron ${ }^{1,3}$

\begin{abstract}
Canada's boreal forest represents an important contributor of the world's wood supply industry. However, maintaining or increasing productivity of the boreal forest may be challenging in areas dominated by forested peatlands. Moreover, sustainable management of these forests must also consider other important aspects of the forest ecosystem such as biodiversity and carbon sequestration. To address these concerns, ecosystem-based management has been implemented in some Canadian jurisdictions, such as in regions where a large portion of the boreal forest is dominated by forested peatlands. The objectives of this paper are (1) to summarize our current understanding of how natural disturbances influence stand dynamics and biodiversity in forested peatlands, and (2) to review the main differences between natural and managed forest stands with respect to soil properties, stand productivity, understory plant communities. We also discuss how even-age management regime succeeds or fails to preserve old forests and how this loss affects both forest structure and habitat diversity at the landscape level. We conclude by showing how, in boreal forested peatlands, forest management could contribute to carbon sequestration and mitigate projected climate change.
\end{abstract}

Keywords: Clearcutting, Fire, Forest dynamics, Partial cutting, Soil properties, Stand productivity, Understory plant communities

\section{Background}

In Canada, boreal forested lands cover approximately 223,000 Mha (i.e. nearly $25 \%$ of Canada's terrestrial area; Brandt 2009). In this forest biome, primary productivity is strongly limited by climatic (e.g. length of the growing season), microclimatic (e.g. low soil temperature), and edaphic (e.g. nutrient availability, waterlogging) factors (Bonan and Shugart 1989; Tamm 1991; Giesler et al. 2002). Despite being relatively unproductive compared to other forest biomes, in 2005 Canada's boreal forest contributed to an estimated 12\% of global (and 32\% of

\footnotetext{
* Correspondence: benoit.lafleur@uqat.ca

${ }^{1}$ NSERC-UQAT-UQAM Industrial Chair in Sustainable Forest Management and Institut de recherche sur les forêts, Université du Québec en

Abitibi-Témiscamingue, 445 boul. de I'Université, Rouyn-Noranda, QC J9X

5E4, Canada

Full list of author information is available at the end of the article
}

Canada; Government of Canada 2017) wood production on a volume basis (Aerts et al. 2011). Canada's boreal forest is therefore at the forefront of the world's wood supply industry. In this context, it is important to seek maintaining or even increasing wood productivity in the Canadian boreal forest using judicious/adapted management strategies and silvicultural practices. However, in some areas of the boreal forest, maintaining or increasing productivity may be a real challenge, especially in areas prone to paludification (the gradual transformation of forested or non-forested uplands into peatlands; Payette and Rochefort 2001) or already covered by forested peatlands (which represents ca. $10 \%$ of the area of Canada's boreal forest; Lavoie et al. 2005a). Furthermore, sustainable management of these forests must also consider other important aspects of the forest ecosystem such 
as maintaining biodiversity and carbon sequestration (Payette and Rochefort 2001; Fenton and Bergeron 2008).

The northern Clay Belt, a vast area (ca. 125,000 km²) of northeastern Canada (Fig. 1), is particularly vulnerable to successional paludification (Simard et al. 2007), i.e. a dynamic process driven by forest succession between fire events that leads to peat accumulation, a concomitant thickening of the soil organic layer (SOL), and the formation of waterlogged conditions on a formerly dry mineral soil (Simard et al. 2007). Long fire-free intervals (ca. 400 years; Bergeron et al. 2004), cold climate, flat topography (plains broken by gentle undulations or ridges), and surficial deposits that are resistant to water penetration (i.e., clay and compacted clay of the Cochrane till) make the Clay Belt especially favorable to landscape paludification (Lavoie et al. 2005b).

Forests in the northern Clay Belt are commercially managed for timber and sustain a regionally important forest industry. Historically, forest stands have been harvested by clearcutting, as it was thought to be compatible with the ecological requirements of the most widespread species, i.e. black spruce (Picea mariana [Mill.] BSP) (Keenan and Kimmins 1993; McRae et al. 2001). However, concerns raised about the protection of soils and tree regeneration during forest operations sparked important changes in harvest methods, and careful logging (which objectives are to protect tree regeneration and soils, and which, therefore, is conducted during winter when the soil is frozen) gradually replaced clearcutting in the 1990s. Over the years it appeared that where organic layer is $>30 \mathrm{~cm}$ thick, careful logging was suspected to favor paludification and to reduce black spruce forest productivity (Fenton et al. 2005; Lavoie et al. 2005b). Reports of declining productivity following careful logging initiated an important research program focusing on the effects of silvicultural treatments on stand productivity for sites prone to paludification with the aim of identifying silvicultural treatments most likely to control paludification and maintain forest productivity (Bergeron et al. 2007; Fenton et al. 2009).

In parallel with the growing concerns about the protection of soils and tree regeneration, and the environmental sustainability of the forestry practices, the Quebec's forest sector was severely impacted by the 2007-2010 recession that followed the collapse of the housing bubble in the US. Together, these events lead to profound reflections on Quebec forest management

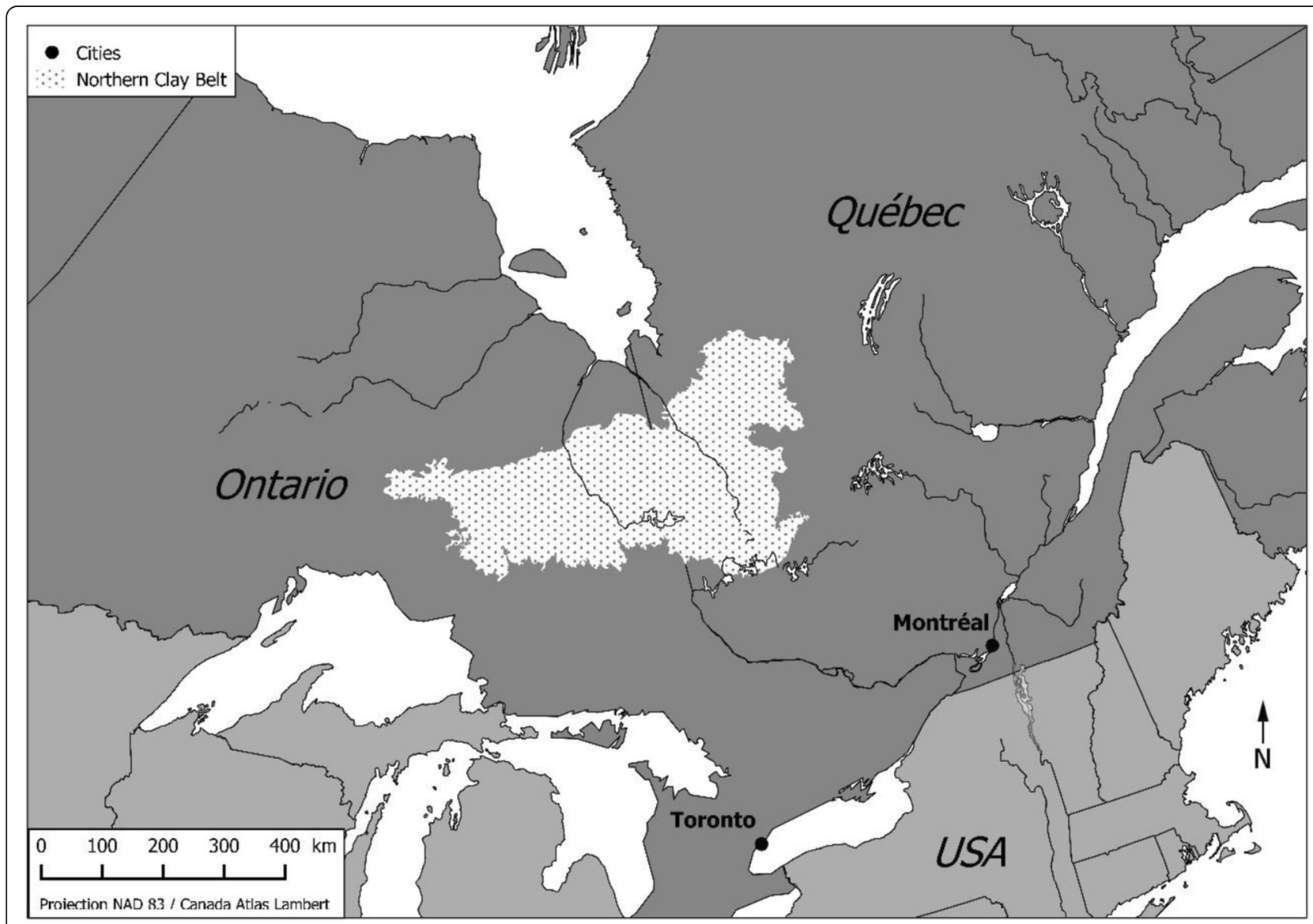

Fig. 1 Location of the Northern Clay Belt in northeastern North America 
and eventually to the adoption of a new forest management regime specifically designed to implement sustainable forest development through ecosystem-based management (Government of Quebec 2017). This approach aims to maintain both productivity and biodiversity of the forested landscapes of Québec (Gauthier et al. 2008). Achieving these two goals however is challenging, at least at the stand scale. For example, biodiversity protection involves maintaining forest structures that are often associated to old forests, which have the additional benefit of storing large amounts of carbon in their organic soils (Fenton et al. 2009). Old forests however are increasingly rare in managed landscapes. Maintaining the abundance of old forests can be achieved through full conservation of old-growth forests but also by using partial cutting, a silvicultural practice that is however susceptible to reduce productivity on paludified sites (Fenton et al. 2009). Nevertheless, reporting on the fifteen-year results of uneven-aged management in forested peatlands, Groot (2013) observed and increase in basal area with time indicating that partial cutting can maintain stands which structure is suitable for the implementation of uneven-aged silviculture through the use of partial cutting.

The main objective of this paper is to report our current understanding of how ecosystem management can be applied in the boreal black spruce peatlands of the Clay Bely. More specifically, we first summarize our current understanding of how natural disturbances shaped this landscape and influenced stand dynamics and biodiversity, and review the main differences between natural and managed forest stands. Then we describe how the former (i.e. clearcutting) and actual (i.e. careful logging around advanced growth [CLAAG]) management regime succeeded or failed to reproduce the structures and conditions of natural stands necessary for biodiversity. We conclude by showing how ecosystem management in paludified boreal forests could contribute to carbon sequestration and mitigate projected climate change.

\section{Black spruce forests as shaped by natural disturbances Natural disturbances}

Over the last two decades, the landscape and stand dynamics of the forests of the northern Clay Belt have been extensively studied (Carleton and Maycock 1978, Carleton and Maycock 1980; Lecomte and Bergeron 2005; Lecomte et al. 2005; Belleau et al. 2011; Bergeron and Fenton 2012). While some studies have focused on natural disturbances (Carcaillet et al. 2001; Bergeron et al. 2004) and stand dynamics (Harper et al. 2003; Gauthier et al. 2004; Lecomte et al. 2006a), others sought to contrast the effects of silvicultural treatments with those of natural disturbances (Nguyen-Xuan et al. 2000; Bescond et al. 2011;
Simard et al. 2001; Arseneault et al. 2012; Lafleur et al. 2010b, Lafleur et al. 2016; Renard et al. 2016).

In the northern Clay Belt, wildfire is the main disturbance agent affecting forests (Bergeron et al. 2004). Reconstruction studies have shown that the mean fire return interval in the region was shorter during the Little Ice Age than it is now, increasing from 100 years before 1850, to 135 years between 1850 and 1920 , to about 400 years since 1920 (Bergeron et al. 2004). While the effects of fire are most evident on the tree component of forest ecosystems, fire also has important effects on understory vegetation and soils. The combustion of the organic layer fosters nutrient release (Neff et al. 2005; Smithwick et al. 2005; Zhang and Biswas 2017) and creates suitable microsites for the regeneration of many tree species (Charron and Greene 2002; Greene et al. 2007). Furthermore, the spatial heterogeneity of soil burn severity is especially important to understand vegetation patterns and forest productivity (Lecomte et al. 2005; Simard et al. 2007). Soil burn severity refers to the amount of SOL combusted during a fire event, and should technically be measured as the percentage of SOL consumed relative to the pre-fire SOL depth. Due to a lack a pre-fire data, this is however impossible to do, so for practical reasons, soil burn severity is usually determined by the thickness of the unburned or residual organic layer (ROL) left after the fire (Nguyen-Xuan et al. 2000; Greene et al. 2005). ROL thickness is also more relevant to forest ecology studies than percent SOL consumed because it influences post-fire stand regeneration and growth (Johnstone and Chapin 2006; Greene et al. 2007). In the field, low-severity soil burns can be identified by the presence of a charcoal layer within the organic soil profile, with a sharp contrast between a well-decomposed (humic) ROL below the charcoal layer and an undecomposed (fibric) or less decomposed organic horizon above. With higher severity soil burns, the charcoal layer lies directly on the mineral soil and no charcoal is found in the SOL (Preston et al. 2017, Fig. 2).

In the black spruce forests of the northern Clay Belt, soil burn severity varies noticeably, with ROL ranging from $1 \mathrm{~cm}$ to more than $15 \mathrm{~cm}$ (Fig. 2; Lecomte et al. 2005, 2006a, Lecomte et al. 2006b; Simard et al. 2007). Residual organic layers thicker than $4-5 \mathrm{~cm}$ have been shown to hamper the establishment of most tree species (Johnstone and Chapin 2006; Greene et al. 2007). For this reason, this value is often used as a threshold to distinguish high-severity ( $\mathrm{ROL}<5 \mathrm{~cm}$ ) from low-severity (ROL > $5 \mathrm{~cm}$ ) soil burns (Lecomte et al. 2005, Lecomte et al. 2006a, Lecomte et al. 2006b). In the northern Clay Belt, soil burn severity is a critical factor in black spruce forest dynamics because it creates alternative successional pathways following fire (Lecomte et al. 2006a). Hence, high- and low-severity soil burns will hereafter refer to this ecologically meaningful threshold. 


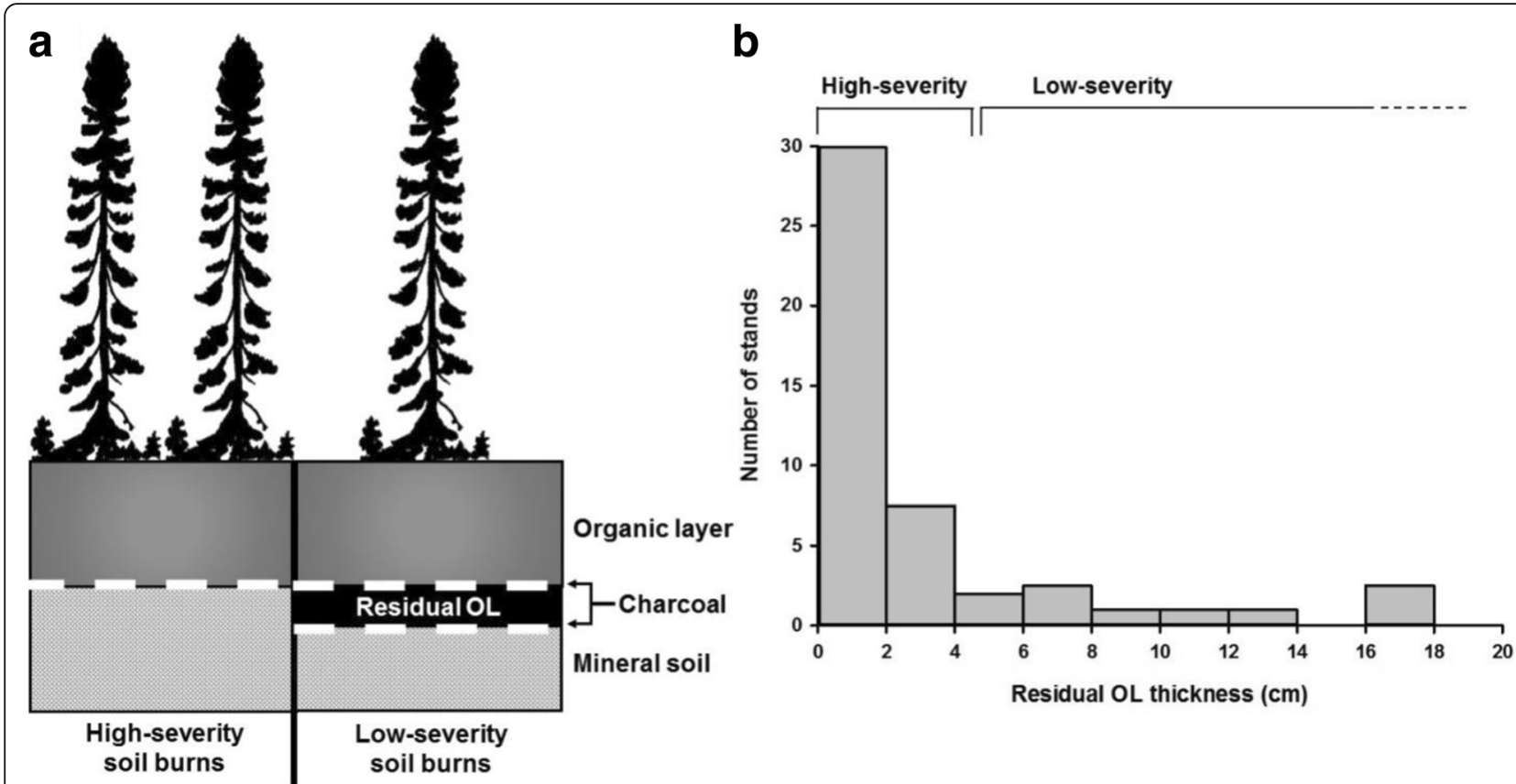

Fig. 2 a High- and low-severity soil burns. High-severity soil burns consume most of the organic layer, leaving charcoal fragments directly on the mineral soil. Low-severity soil burns only partially burn the organic layer and leave a distinctive residual (unburned) organic layer (ROL). b The thickness of the ROL makes it possible to differentiate stands established after high- $(\mathrm{ROL}<5 \mathrm{~cm})$ and low-severity soil burns (ROL $>5 \mathrm{~cm})$. Modified from Simard et al. 2007 and Simard et al. 2009

As they mature, the boreal forests of northeastern North America become susceptible to insect pest (Taylor and MacLean 2009), especially the eastern spruce budworm (Choristoneura fumiferana Clem.), and windthrow (Ruel 1995). Black spruce forests of the northern Clay Belt, however, are not affected as frequently by severe outbreaks of insect pests as black spruce forests located elsewhere in the boreal biome (Gray et al. 2000; Morin et al. 2009). Spruce budworm actually affects a smaller area $(<1 \%$ for all stand age classes; about $2 \%$ for the 100 to 250 -year-old class) than windthrow (9\% for all stand age classes; $15 \%$ for the 100 to 250 -year-old class; Harper et al. 2002, Harper et al. 2003).

\section{Forest dynamics}

Following fire, regeneration in the forested peatlands of the northern Clay Belt is dominated by black spruce. Nevertheless, the pioneer species Jack pine (Pinus banksiana Lamb.) and trembling aspen (Populus tremuloides Michx.) can also be present in pure or mixed even-aged stands (Harper et al. 2002; Lecomte and Bergeron 2005; Lecomte et al. 2006a; Simard et al. 2009). In both jack pine and trembling aspen stands, succession leads progressively (i.e. ca. 100 years after fire) to the replacement of these short-lived species by the shade-tolerant black spruce and about 200 years after fire, $>90 \%$ of stands are dominated by black spruce (Fig. 3, Harper et al. 2002; Simard et al. 2009).
Whereas post-fire stands of mixed composition (comprising Jack pine or aspen) undergo species succession, post-fire stands dominated by black spruce undergo structural succession. After fire, black spruce establishes mainly by seed and constitutes an even-aged structural cohort (i.e. trees of similar size) (Groot and Horton 1994; Lecomte et al. 2006a). Between ca. 100 and 200 years after fire, as trees of the post-fire cohort begin to die (because of aging, localized secondary disturbances, such as wind or pest insects, or pathogens), the canopy gradually opens

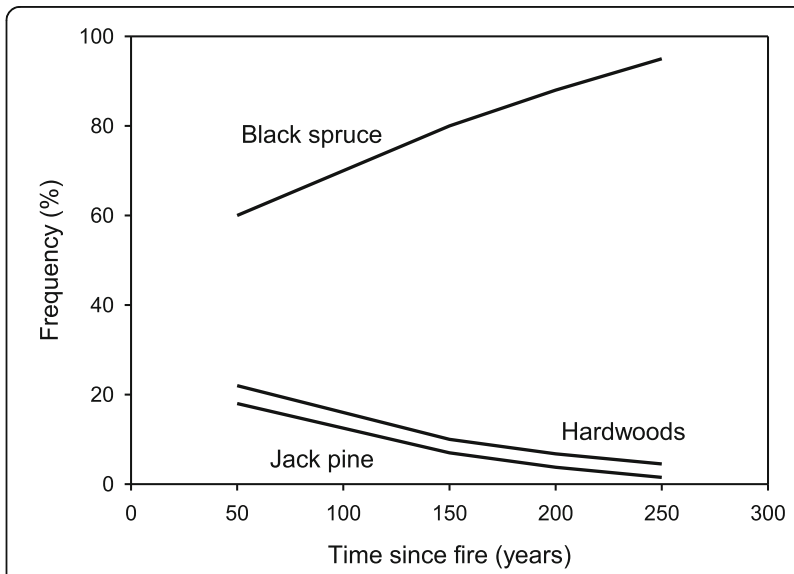

Fig. 3 Tree species succession with time since fire. Modified from Simard et al. (2009) with original data from Gauthier et al. (2000), Harper et al. (2002), Harper et al. (2003), and Lecomte et al. (2005) 
up, leading to the constitution of a second cohort of smaller stature partly established by layering. In the prolonged absence of fire (i.e. 250 years or more), a third cohort of uneven-aged stands develops. Second- and third-cohort stands have a heterogeneous structure and are comprised of fewer and smaller trees $(<10 \mathrm{~m}$ high) with abundant snags (Fig. 4; Groot and Horton 1994; Harper et al. 2002; Lecomte et al. 2006a).

Concomitantly to tree species and structural succession, black spruce stands of the Clay Belt experience a thickening of the organic horizon with time since fire, which paves the way for paludification. The thickness of this organic layer is influenced by topography and surface morphology (Laamrani et al. 2015), which in turn influence forest dynamics at both the stand and landscape level. The structural changes, outlined above for high-severity soil burns, in fact strongly depend on soil burn severity (Lecomte et al. 2006a; Simard et al. 2007). On the one hand, stands of the first cohort that develop after high-severity soil burns are rooted in the mineral soil (or in thin $(<5 \mathrm{~cm}) \mathrm{ROL}$ ) and are characterized by a rapid closure of the canopy that culminates ca. 100 years after fire (Lecomte et al. 2006b; Simard et al. 2007). With time, feathermosses, which establish soon after fires, are replaced by sphagnum and organic material accumulate. As the organic layer gets thicker, newly established trees are mainly rooted in this organic horizon, which constitutes a poorer/harsher growth substrate than mineral soil. Consequently, trees that form the second cohort never reach the size of trees from the first post-fire cohort. As the organic material accumulates further, tree height of successive cohorts becomes smaller and more variable (Fig. 5) (Lecomte et al. 2006a; Simard et al. 2007).

On the other hand, stands that establish after low-severity soil burns are more open, are made up of smaller stems (Lecomte et al. 2006a), and are less productive (Simard et al. 2007) than those originating from high-severity soil burns because tree roots are located in the ROL. In addition, because of the spatial heterogeneity in ROL thickness caused by variable combustion (Greene et al. 2007; Lavoie et al. 2007), stands that establish after low-severity soil burns display two distinct height classes, instead of having a single-storied canopy like stands originating from high-severity soil burns (Lecomte et al. 2006a). Ultimately, young post-fire stands originating from low-severity soil burns show the same structure as very old stands from high-severity soil burns (Simard et al. 2007).

\section{Biodiversity}

The disturbance regime and forest dynamics of the Clay Belt determine the characteristics of the forest landscape that is the habitat for forest-dependent species (Harper et al. 2003; Bergeron et al. 2004; Cyr et al. 2005). Forest-dependent species of bryophytes, lichens and invertebrates make up the most species rich groups across the landscape (Paradis and Work 2011; Bergeron and Fenton 2012). These groups respond to fire severity and changes in forest structure (Boudreault et al. 2009; Paradis and Work 2011; Bergeron and Fenton 2012; Fenton and Bergeron 2013; Doblas-Miranda and Work

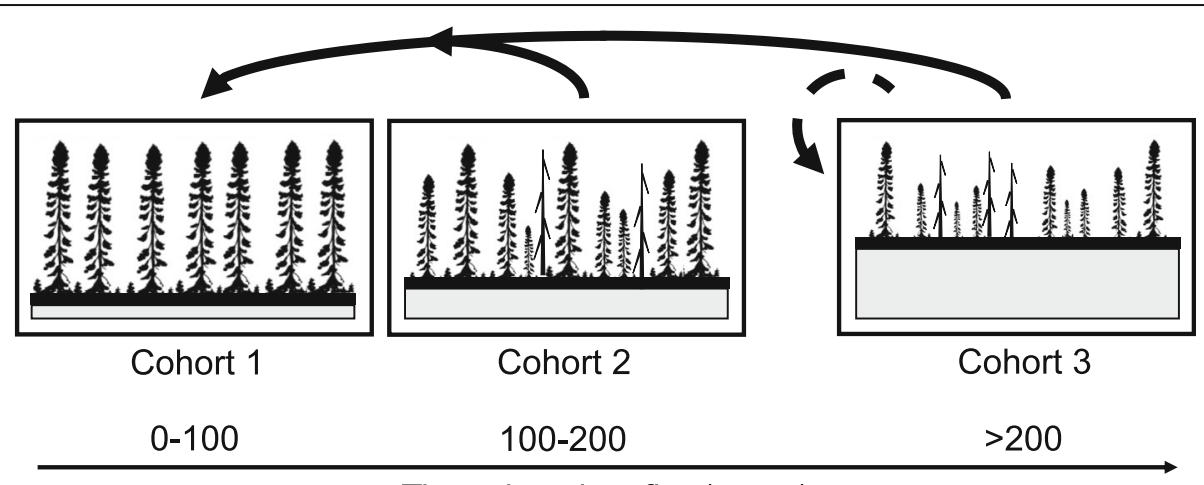

Time since last fire (years)
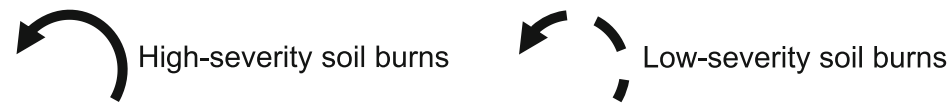

Fig. 4 In paludified forests, stand dynamics can be synthesized using the cohort approach (Bergeron et al. 1999; Harvey et al. 2002). With this approach, it is possible to illustrate forest succession in a simple way by classifying forest stands in one of three cohorts that differ according to their age and structure, and that roughly correspond to early-, mid-, and late-successional stages of forest succession. High-severity soil burns convert these stands to first cohort stands, whereas low-severity soil burns, by not completely consuming the organic layer (gray area under the stands), create low-productivity forests that are structurally similar to third-cohort stands. Modified from Lecomte et al. (2006a), Simard et al. (2009), and Fenton et al. (2009) 


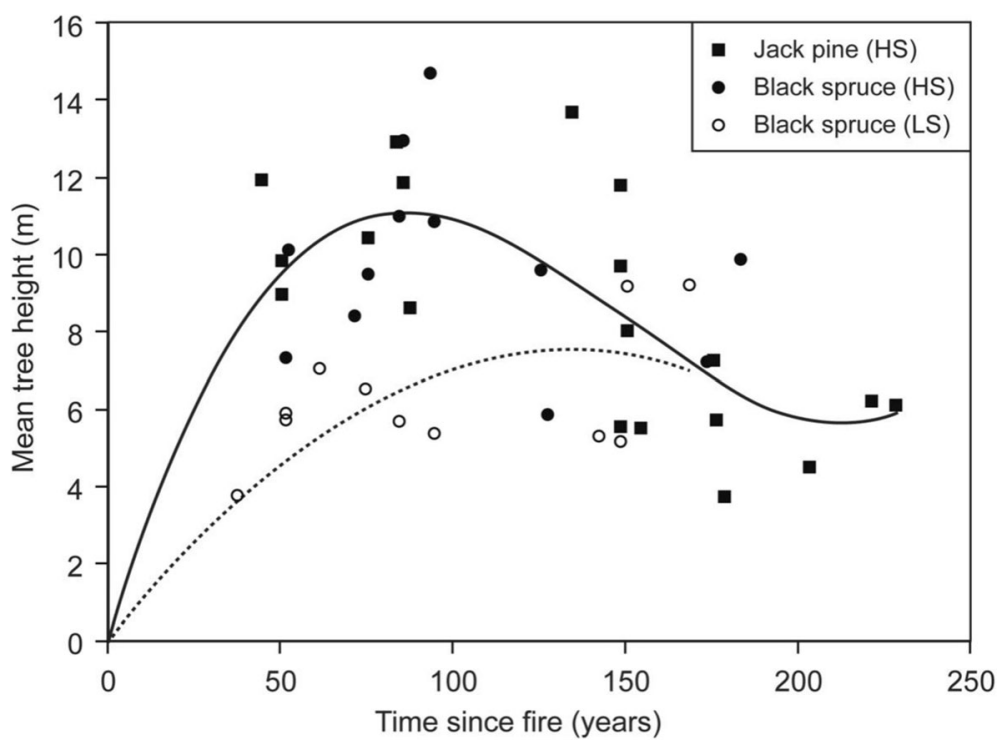

Fig. 5 Changes in stand height with time since fire and soil burn severity. The solid line represents jack pine and black spruce stands originating from high-severity soil burns and the dashed line represents black spruce stands originating from low-severity soil burns. Modified from Lecomte et al. (2006a)

2015). Since each of these species are associated with specific stand structures, community composition is greatly influenced by soil burn severity and time elapsed since fire (Bergeron and Fenton 2012; Boudreault et al. 2009; Paradis and Work 2011; Fenton and Bergeron 2013; Doblas-Miranda and Work 2015).

Examining the diversity dynamics in more detail, after high-severity soil burns, young dense stands are relatively poor in terms of bryophytes, spiders and orbatid mites. However, the structurally diverse second-cohort stands that are at an intermediate level of paludification are particularly rich in bryophtes, spiders, orbatid mites, and birds (Fenton and Bergeron 2008; Paradis and Work 2011; Doblas-Miranda and Work 2015). This is partially due to the presence of microhabitats, particularly deadwood and canopy gaps (Fenton and Bergeron 2008; Paradis and Work 2011; Doblas-Miranda and Work 2015; Cadieux and Drapeau 2017). Ultimately, diversity declines in all of these groups as paludification continues and stands open up completely and deadwood is buried in the organic layer, reducing its availability (Moroni et al. 2015).

In contrast, after low-severity soil burns, the open character of the regenerated stands with less standing dead wood limit the development of diverse structures, including deadwood. Consequently, overall diversity is lower and dominated by peatland specialists (Fenton and Bergeron 2008).

All the studies outlined above clearly highlight the importance of soil burn severity, soil organic layer thickness, and paludification on forest productivity and understory biodiversity in the northern Clay Belt. They also emphasize the importance of understanding how natural disturbances and successional dynamics shape forest stands and landscapes to successfully and sustainably manage paludified boreal forest ecosystems.

\section{Old-growth forests}

Old-growth forests constitute an ecologically important component of forest landscapes (Writh et al. 2009). In fire-dominated forest landscapes, old-growth forests can be defined as forests that are no longer dominated by individuals or species that established immediately after fire (i.e. individual or species of the postfire cohort) (Kneeshaw and Gauthier 2003). However, in forest landscapes dominated by a single species (i.e. where no species replacement occurs during succession), such as is the case in the black spruce-dominated Clay Belt, old-growth forests can be best described by their complex structure. At the stand level, such complex structures are the result of time since fire (Martin et al. 2018) and secondary disturbance (such as insect outbreaks or windthrow), which allow for the recruitment of younger and smaller tree in the canopy (Kneeshaw and Gauthier 2003). As a result, the complex structures of old-growth stands are expressed by their irregular, uneven-aged character (Kneeshaw and Gauthier 2003). At the landscape level, this complexity is reflected by the mosaic of forest stands of different ages and structures (i.e. a mixture of regular, even-aged stands and irregular, uneven-aged stands) (Kneeshaw and Gauthier 2003; Cyr et al. 2005). 
While it is indisputably true that boreal forests are less species rich than similar forests closer to the equator, this view does not hold for all types of boreal forests or species groups (especially bryophytes and lichens). Indeed, old-growth boreal forests typically harbor species (both plants and animals) assemblages that differs from younger forests (Drapeau et al. 2003). For instance, Bergeron and Fenton (2012) found that stand-level species richness of both vascular and nonvascular plants increased significantly 150 years after fire. Old-growth boreal forests, therefore, can harbor a diverse understory community that is absent in younger stands. As old-growth forests constitute only a small fraction of boreal forest landscapes, the loss of theses stands (for instance to logging) could result in a significant loss of species (Esseen et al. 1997; Siitonen 2001).

How do natural and managed black spruce forests differ? Over the past decade, several studies have compared the effects of logging and fire on soil properties, tree growth, stand productivity, and understory vegetation in the northern Clay Belt (Nguyen-Xuan et al. 2000; Simard et al. 2001; Fenton and Bergeron 2007; Fenton et al. 2009; Lafleur et al. 2010b, Lafleur et al. 2016; Renard et al. 2016). More specifically, these studies compared several logging methods (i.e. clearcutting, careful logging around advanced growth, and partial harvesting), logging seasons (i.e. summer and winter), and burn severity (prescribed burning and high- and low-severity soil burns).

\section{Differences in soil properties}

In the northern Clay Belt, one of the most visible effects of wildfire and logging on soil properties can be seen in the thickness of the soil organic layer (SOL). While both disturbances reduce SOL thickness relative to undisturbed forest sites, fire reduces SOL thickness to a greater degree than logging (Simard et al. 2001). In addition, differences in soil disturbance severity, whether caused by fire or logging, also result in differences in SOL thickness: stands experiencing high-severity soil burns have significantly thinner SOL than those experiencing low-severity soil burns and logging methods that severely disturb the SOL, such as clearcutting, have a greater potential to reduce SOL thickness than methods dedicated to soil protection such as careful logging (Lafleur et al. 2016). The effect of logging methods is further modulated by logging season, logging conducted during summer resulting in thinner SOL than logging conducted during winter (Lafleur et al. 2010b).

Forest floor removal by fire can impact long-term site productivity through the loss of soil organic matter and modifications to nutrient supply (Certini 2005). Simard et al. (2001) found that in the black spruce forest of the Clay Belt, soil burns reduced organic carbon content compared to logging. Nitrogen losses (especially through volatilization) have been frequently reported in various ecosystems (e.g., Johnson and Curtis 2001; Wan et al. 2001; Boerner et al. 2009; Nave et al. 2011; Kishchuk et al. 2014; Maynard et al. 2014), and several studies have shown that base cation (i.e. $\mathrm{K}^{+}, \mathrm{Ca}^{++}, \mathrm{Mg}^{++}$) concentrations are usually higher in the forest floor following fire than after logging (Simard et al. 2001; Thiffault et al. 2007). However, in the Clay Belt, both Simard et al. (2001) and Lafleur et al. (2016) failed to detect any differences in total $\mathrm{N}$ and base cation concentrations between burned and logged stands. Nevertheless, Simard et al. (2001) found that approximately 20 years after disturbance concentrations of $\mathrm{N}$ and $\mathrm{Ca}$ were significantly higher in disturbed stands (either by fire or logging) relative to control stands. Moreover, Simard et al. (2001) found that logged stands had a greater total mass of nutrients $(\mathrm{N}, \mathrm{P}$ and $\mathrm{Ca}$ ) than either burned or control stands, whereas the concentration and mass of mineralizable $\mathrm{N}$ in the forest floor were significantly greater in logged than in burned and control stands.

These results suggest that both clearcutting and wildfire can produce a pulse of nutrients, and that the magnitude of the pulse is dependent on the type of disturbance and nutrient that are considered. Whereas the combustion of organic matter during fire generates a pulse of available nutrients, logging, through the input of leaf litter and small branches, increase the mass of forest floor organic matter and produce a nutrient pulse through the mineralization of this new available fresh organic matter. In turn, this suggests that regenerating trees are likely to be exposed to greater amounts of available nutrients in burned than in logged sites, but that logged stands, with their greater amount of total nutrients in the forest floor, have a greater capacity than burned stands to supply nutrients to support forest productivity. In addition, in both cases, the disruption of the bryophyte cover is likely to change soil physical conditions and speed up nutrient cycling (Lafleur et al. 2011).

\section{Differences in stand productivity and foliar nutrition}

In the boreal forest, the growth of regenerating stands is influenced by the nature and the severity of the disturbance, such as fire and logging (Martin and Gower 2006; Girard et al. 2008). This phenomenon is particularly obvious in paludified stands and landscapes prone to paludification where soil disturbance severity have a profound influence on tree growth and forest productivity. With respect to fire, Lecomte et al. (2006b) and Simard et al. (2007) both showed that forest productivity was lower following low-severity soil burns compared to high-severity soil burns. Following high-severity soil burns, regenerating trees establish on a thinner ROL, which allows tree roots to access the mineral soil where nutrient availability 
(notably N and P) is higher (Simard et al. 2007); in contrast, after low-severity soil burns, regenerating trees establish on a thicker ROL characterized by lower nutrient concentrations, waterlogged conditions, and reduced access to mineral soil, which altogether limit root elongation, nutrient uptake, and tree growth (Simard et al. 2007). In the same vein, Lafleur et al. (2010a), Lafleur et al. (2010b) showed that 10 to 20 years after harvesting forest productivity was lower following logging methods dedicated to soil protection such as careful logging compared to logging methods, such as clearcutting, where machinery trafficking is allowed across the entire cutover area. Furthermore, Lafleur et al. (2010b), Lafleur et al. (2016) showed that clearcutting conducted during summer regenerate stands that are as productive as those regenerating after high-severity soil burns.

Higher soil $\mathrm{N}$ and $\mathrm{P}$ concentrations and/or accessibility following high-severity soil burns and summer clearcutting can be reflected in foliar nutrition. Simard et al. (2007) observed higher foliar $\mathrm{N}$ and P concentrations after high-severity soil burns than after low-severity soil burns. Similarly, Lafleur et al. (2016) showed the foliar N and $\mathrm{P}$ concentrations were similar in trees established after both high-severity soil burns and clearcutting, whereas Lafleur et al. (2010b) showed that foliar N concentrations was higher after clearcutting than after careful logging around advanced growth.

In the case where high productivity is the main silvicultural objective, these results suggest that in paludified stands (or those in the process of being paludified), severe soil disturbance during harvesting is essential to promote tree regeneration and growth, and maintain stand productivity levels comparable to those observed in stands established after high-severity soil burns.

\section{Differences in understory vegetation}

In paludified boreal landscapes, disturbance type (i.e. natural vs. anthropogenic) and severity may influence the composition of the understory plant communities. In a study conducted in the northern Clay Belt, Nguyen-Xuan et al. (2000) found that plant communities established after fire were different than those established after clearcutting, a pattern they attributed to the greater impact of fire on the forest floor compared to clearcutting. They also observed that understory ground cover of post-fire stands was dominated by the crustose lichen Trapeliopsis granulosa (Hoffm.) Lumbsch, whereas in logged stands the ground was mostly dominated by the feathermoss Pleurozium schreberi. Nguyen-Xuan et al. (2000) also observed that avoiders (see Rowe (1983) for a thorough discussion on boreal species mode of persistence after disturbance) were associated to logged stands, whereas invaders of xeric environments were highly associated to burned stands; endurers could be found after either wildfire or logging.
More recently, Lafleur et al. (2016) also showed that in paludified sites, disturbance type could significantly affect the relative abundance of understory vascular plants and bryophytes. For instance, they observed that the ground cover of the ericaceous species $R$. groenlandicum (an important competitor of black spruce) was significantly lower in sites where soils were severely burned or severely mechanically disturbed by clearcutting relative to sites where soils were only superficially burned (i.e. low severity fires). Likewise, the ground cover of Sphagnum spp. was significantly lower in sites where soils were severely burned or severely mechanically disturbed by clearcutting relative to sites where soils were protected by the application of careful logging around advanced growth.

Together, the two studies emphasize the importance of disturbance type (i.e. natural vs. anthropogenic) and severity on understory plant community composition in paludified forests. Restricting circulation of logging machinery to evenly-spaced trails, such as during careful logging around advanced growth, leaves the understory vegetation and soils intact between the trails, which may induce rapid proliferation of ericaceous species such as $R$. groenlandicum and $K$. angustifolia (Lorente et al. 2012). These species may compete directly with trees for nutrients, and indirectly by modifying humus quality and inducing allelopathic effects (Thiffault et al. 2013). In contrast, by disturbing the organic layer in which the roots of ericaceous shrub proliferate (Mallik 1993; Hébert and Thiffault 2011), clearcutting can limit shrub proliferation and their negative effect on tree growth. Similarly, high-severity soil burns may kill the roots of ericaceous shrubs, whereas low-severity soil burns have the potential to stimulate their vegetative reproduction through sprouting and rhizomes growth (Mallik 2003).

These findings support the idea that site properties, especially soil organic layer thickness and ericaceous shrub abundance, should be taken into account in the development of forest management strategies in paludified forest landscapes. They also support the idea that in areas where management strategies are mainly aimed at regenerating paludified forests, severe soil disturbance (either mechanical or by fire) can be used to reduce SOL thickness and ericaceous shrub cover. In this context, logging methods that disturb the surficial layers, such as traditional clearcutting, ideally followed by prescribed burning, are to be preferred to careful logging practices on sites prone to paludification such as those found in the Northern Clay Belt.

\section{Loss of old forests}

When forest rotation age approaches fire cycle, at first glance even-aged management would appear to resemble the natural disturbance regime. However, full even-age 
regulation does not produce an age class distribution equivalent to the natural distribution, even for forest rotations that are as long as the fire cycle. In effect, in even-aged management a forest is referred to as fully regulated when stand age classes are uniformly distributed throughout a landscape. Thus, in theory, after one complete rotation in a region submitted to a 100 year rotation, no stands over the rotation age will exist. The same region submitted to forest fires intense enough to generate even-aged stands will, at equilibrium, present a completely different age class distribution of stands composing the forest. This means that for a fire cycle and a forest rotation of similar duration, forest management will not spare any forest that exceeds rotation age whereas fire will maintain over 37\% of the forest in older age classes (Johnson and Van Wagner 1985; Bergeron et al. 2007). This difference is fundamental because it implies that full regulation in an even-age management regime will result in the loss of over-mature and old growth forests, often judged to be essential for the maintenance of biodiversity. In the northern Clay Belt, natural mosaic contains almost 50\% of forests aged from more than 100 years. Thus, the loss of over mature old-growth forests constitutes the first major difference between current forest management and natural disturbance for the northern Clay Belt.

Use of rotations of variable length in proportions similar to those observed in the natural fire regime is a possible alternative (Burton et al. 1999; Seymour and Hunter 1999) to maintain old growth-forests. However, the approach may be applicable only in ecosystems where species are long-lived and can thus support longer rotations. In boreal forests composed of relatively short-lived species this approach would probably lead to fibre loss and a decrease in allowable cut. Alternatively, Bergeron et al. (1999) have suggested that silvicultural practices aimed at maintaining structural and compositional characteristics of over-aged stands in treated stands could, in boreal regions, guarantee maintenance of habitat diversity while only slightly affecting allowable cut. In addition to usual clear-cutting followed by seeding or planting (or another even-age silvicultural system whose outcome resembled to post-fire conditions), some stands could be treat by partial cuts which approach the natural development of over-aged stands (Groot 2013) and still other stands with selection cuts in order to reflect the dynamics of old growth stands. The current challenge, however, is to identify sites characteristics (e.g. organic layer thickness threshold) that would help forest managers identify sites where clear-cutting may not be applicable, but where partial cuts may be desirable.

A simple example illustrating relationships between natural dynamics and management of the black spruce forest is presented in Fig. 6. Varying silvicultural practices is intended to recreate a composition and structure comparable to natural forest mosaic. Thus the irregular structure of old forest would be maintained or stimulated by partial cutting practised in stands with even or uneven-aged structure (Groot 2013). In the case of the uneven structure of older stands, it could be generated by selection harvesting to mimic the creation of characteristic gaps of old growth forest. The proportion of stands submitted to each of these treatments will vary depending on the natural disturbance cycle and minimum harvest age.

\section{Ecosystem management and carbon sequestration}

It is now highly recognized that boreal forests play a prominent role in the global carbon cycle, notably by

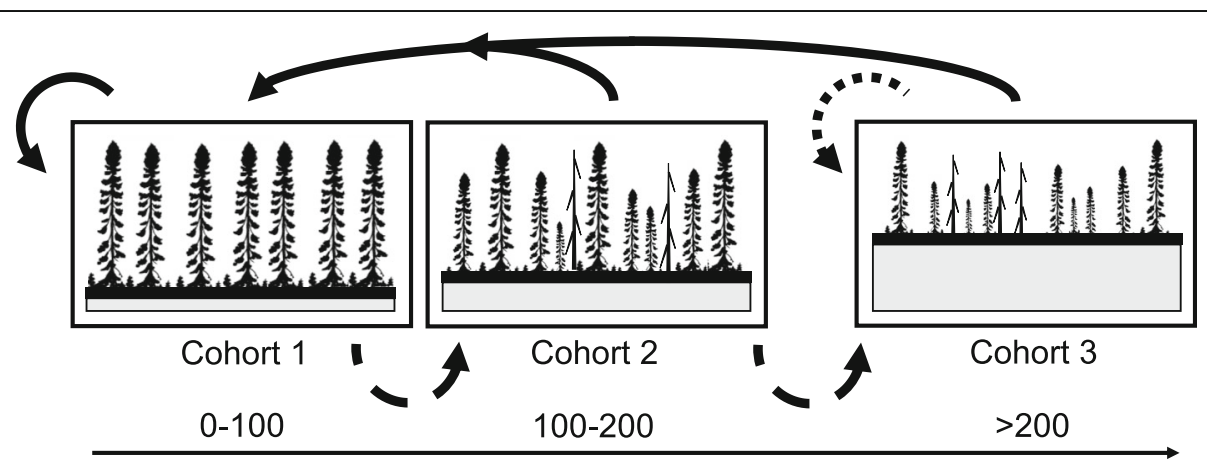

Time since last fire or harvest (years)
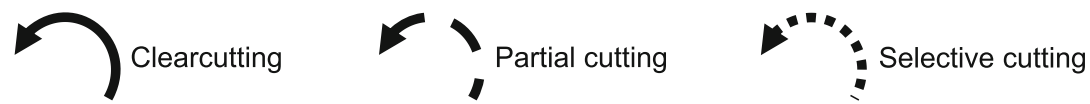

Fig. 6 Suggested silvicultural treatments to emulate natural stand dynamics and structure (refer to Fig. 5). Partial cuts are proposed to emulate succession of first to second cohorts and second to third cohorts, whereas selection cuts are proposed to maintain third cohort structures. Second and third cohort stands can be transformed, and first cohort stands maintained, into first cohort stands by clearcutting (with or without site preparation and planting). Modified from Bergeron et al. (2007) and Fenton et al. (2009) 
a Changes in carbon pools with post-fire succession

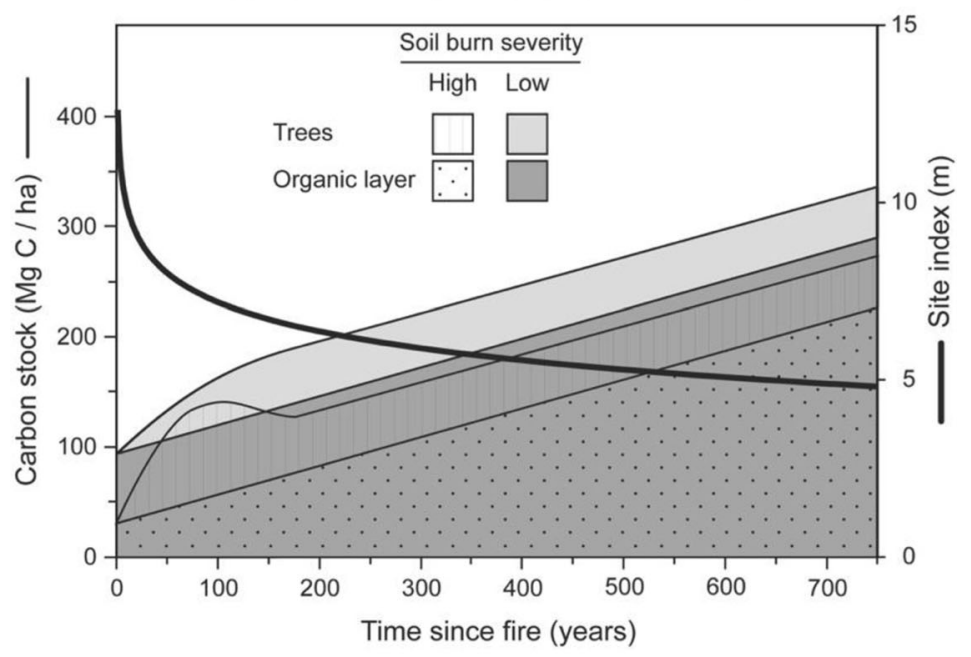

b Effect of mean fire return interval

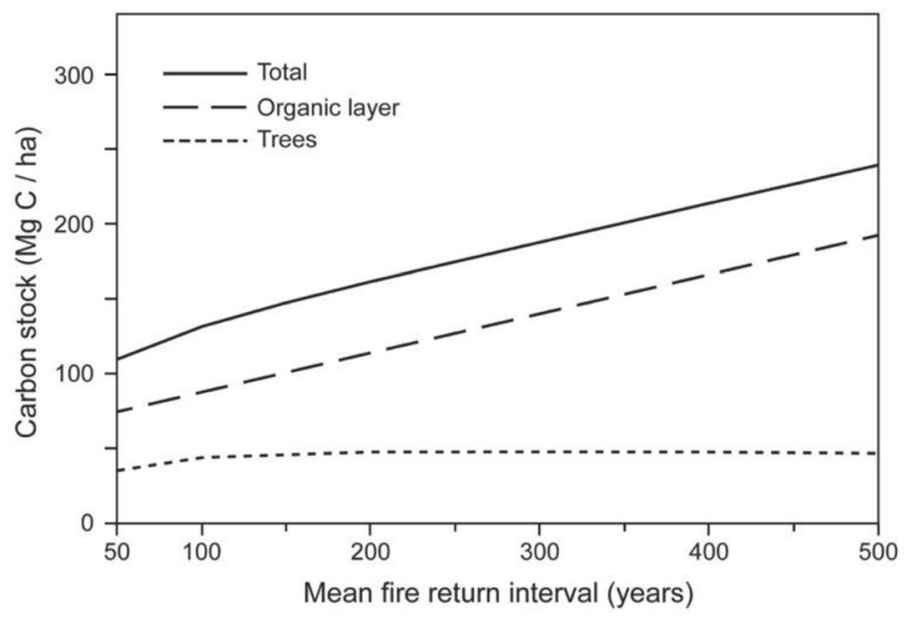

C Effect of soil burn severity

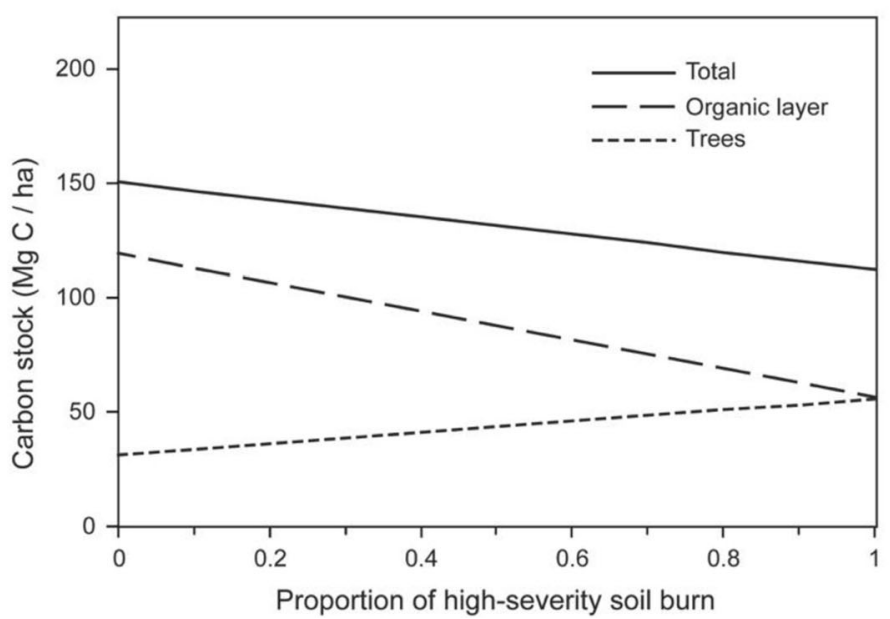

Fig. 7 (See legend on next page.) 
(See figure on previous page.)

Fig. 7 a Stand-level changes in tree and soil organic layer carbon stocks with time since fire for high- and low-severity soil burns. Site index at 50 years is also shown (low- and high-severity soil burns combined). Effect of B) mean fire return interval and C) proportion of stands originating from high vs. low-severity soil burns on carbon stocks. In $\mathbf{b}$, proportion of high-severity soil burns was set to 0.5 and in $\mathbf{c}$, mean fire return interval was set to 100 years. In $\mathbf{b}$ and $\mathbf{c}$, stand age distribution is assumed to be at equilibrium with the fire regime and to follow a negative exponential distribution. Data in A) modified from Lecomte et al. (2006b) and Simard et al. (2007)

sequestering an important part of the anthropogenic $\mathrm{CO}_{2}$ emissions, thereby mitigating climate change (Bradshaw and Warkentin 2015). These forests store huge amounts of carbon, especially in the soil organic layers of paludified stands (Lavoie et al. 2005a; Lecomte et al. 2006b). In these forests, fire and logging regimes directly influence carbon exchanges between the atmosphere and the biosphere. Consequently, silvicultural practices and forest management strategies conducted at a regional scale can have an impact at the global scale.

In the Northern Clay Belt, stands originating from high-severity soil burns have a relatively high growth rate and thin organic layers; consequently, large amounts of $\mathrm{C}$ are stored in tree biomass in the first 100 to 200 years after fire (Fig. 7a; hatched area). The opposite is observed in old-growth stands, where thick organic layers are detrimental to wood production (Fig. 7a). Stands originating from low-severity soil burns show relatively thick organic layers (i.e. large amounts of residual organic matter), which results in young stands storing more carbon in the organic layer than in the tree layer (Fig. 7a). At the stand level, site productivity (quantified by the site index or by tree biomass), is inversely proportional to the total amount of $\mathrm{C}$ stored (Fig. 7a). Therefore, for a given site, it is impossible to maximize in situ $C$ sequestration and wood production at the same time. In other words, converting an old paludified stand to a young, productive stand will necessarily release more $\mathrm{C}$ than the young stand will sequester on the short term.

At the landscape scale, the disturbance regime influences stand age distribution, which in turn influences the amount of $\mathrm{C}$ stored in the ecosystem (Fig. 7b). Short fire return intervals result in landscapes composed of younger stands, with relatively low $\mathrm{C}$ stocks, which are distributed evenly between the aboveground and belowground compartments. When the fire return interval is long, the landscapes are dominated by old stands that store large amounts of $\mathrm{C}$ in their organic layers. Similarly, soil burn severity influences landscape-scale $\mathrm{C}$ storage (Fig. 7c). For a given fire return interval, if most fires are high-severity soil burns, the landscape will be dominated by productive stands with relatively thin organic layers and high tree biomass. A higher proportion of low-severity soil burns at the landscape level results in higher overall $\mathrm{C}$ storage, with most of it stored in organic layers. This highlights how much disturbance regimes, whether natural or anthropogenic, can influence the amount of $\mathrm{C}$ stored in a given region. The $\mathrm{C}$ stored in tree biomass is especially sensitive to changes in the proportion of stands originating from low- or high-severity soil burns (Fig. 7c). This proportion, however, may change very rapidly following modification in the fire regime (including seasonality), silvicultural practices, or fire management. Forest management objectives aiming at maximizing wood production at the landscape level as well as in situ carbon stocks would be most appropriate as the biomass that is removed from the forest through harvesting for bioenergy and wood products can substitute for more emissions-intensive products. A goal of maximizing ecosystem carbon storage ignores these other forest-related influences on greenhouse gas concentrations in the atmosphere. A goal of minimizing net emissions to the atmosphere should take into account the system as a whole (Lemprière et al. 2013). To obtain a clear picture of the climate change mitigation of different management strategies in a paludifying landscape is a difficult task. Indeed, outcomes are complexified by uncertainties related to future disturbance regimes and to the complexity of in situ $\mathrm{C}$ stock changes with time since disturbance and disturbance severity. In this context, tradeoffs between the mitigating effect of the wood product stream and in situ $\mathrm{C}$ storage are likely.

\section{Conclusion}

Accounting for natural dynamics of boreal forested peatlands could assist forest managers in maintaining forest productivity without compromising biodiversity and carbon sequestration. In the northern Clay Belt region, three characteristics of the regional forest dynamics should be taken into account: 1) paludification is pervasive and widespread and has important consequences for the diversity and productivity of stands; 2) Soil burn severity is highly variable and affects tree regeneration, forest productivity and succession, and biodiversity; 3 ) a large part of the forest mosaic is compose of old forests which important habitats for biodiversity; 4) most stands show little or no tree species replacement during succession, and as a result, changes in stand structure are of particular importance. In this context, proposed silvicultural solutions produce opposing results: partial and selection cuts, with little soil disturbance promotes the maintained old forests attributes with high soil carbon stocks, oppose to intensive silvicultural practices that increase forest productivity but 
decrease the soil carbon pool. While these two strategies appear to serve opposed objectives, they are the outcome of a management strategy based on natural disturbances. Both severe stand-replacing disturbances (i.e., fire) and secondary disturbances (tree mortality by blow downs, insect outbreaks, etc.) are important on this landscape, and create a complex mosaic of both even- and irregularly-aged/sized stands. As a result, any management strategy that aims at maintaining biodiversity and ecosystem function by emulating natural disturbances needs to take both of these types of disturbances into account.

\section{Acknowledgements}

We thank Sylvie Gauthier, Cécile Leroy, Sébastien Renard, and Nicolas Lecomte for access to data and original figures.

\section{Author's contributions}

BL drafted the manuscript, BL and MS drew the figures, and all authors contributed to the writing of the manuscript. All authors read and approved the final manuscript.

\section{Ethics approval and consent to participate}

Not applicable.

\section{Consent for publication}

Not applicable.

\section{Competing interests}

The authors declare that they have no competing interests.

\section{Author details}

${ }^{1}$ NSERC-UQAT-UQAM Industrial Chair in Sustainable Forest Management and Institut de recherche sur les forêts, Université du Québec en Abitibi-Témiscamingue, 445 boul. de I'Université, Rouyn-Noranda, QC J9X 5E4, Canada. Department of Geography, Laval University, Québec, QC G1V 0A6, Canada. ${ }^{3}$ Centre d'étude de la forêt, Université du Québec à Montréal, 141 Avenue du Président-Kennedy, Montréal, OC H2X 1Y4, Canada. ${ }^{4}$ Ressources Naturelles Canada, Service canadien des forêts, Centre de foresterie des Laurentides, 1055 du P.E.P.S., P.O. Box 3800, Québec, QC G1V $4 C 7$, Canada.

Received: 8 May 2018 Accepted: 29 June 2018

Published online: 10 July 2018

\section{References}

Aerts EJMM, van der Meer PJ, Verwer CC, Hengeveld GM, Tolkamp GW, Nabuurs GJ, van Oorschot M (2011) Global wood production, assessment of industrial round wood supply from forest management systems in different global regions. Alterra-rapport 1808, Alterra Wageningen UR. Wageningen, The Netherlands

Arseneault J, Fenton NJ, Bergeron Y (2012) Effects of variable canopy retention harvest on epixylic bryophytes in boreal black spruce - feathermoss forests. Can J For Res 42:1467-1476

Belleau A, Leduc A, Lecomte N, Bergeron Y (2011) Forest succession rate and pathways on different surface deposit types in the boreal forest of northwestern Quebec. Ecoscience 18:329-340

Bergeron Y, Drapeau P, Gauthier S, Lecomte N (2007) Using knowledge of natural disturbances to support sustainable forest management in the northern Clay Belt. For Chron 83:326-337

Bergeron Y, Fenton NJ (2012) Boreal forests of eastern Canada revisited: old growth, nonfire disturbances, forest succession, and biodiversity. Botany 90 : 509-523

Bergeron Y, Gauthier S, Flannigan M, Kafka V (2004) Fire regimes at the transition between mixedwood and coniferous boreal forest in northwestern Quebec. Ecology 85:1916-1932
Bergeron Y, Harvey B, Leduc A, Gauthier S (1999) Forest management guidelines based on natural disturbance dynamics: stand- and forest-level considerations. For Chron 75:49-54

Bescond H, Fenton NJ, Bergeron Y (2011) Partial harvests in the boreal forest: response of the understory vegetation five years after harvest. For Chron 87: 86-98

Boerner REJ, Huange J, Hart SC (2009) Impacts of fire and fire surrogate treatments on forest soil properties: a meta-analytical approach. Ecol Appl 19:338-358

Bonan GB, Shugart HH (1989) Environmental factors and ecological processes in boreal forests. Ann Rev Ecol Syst 20:1-28

Boudreault C, Bergeron Y, Coxson D (2009) Factors controlling epiphytic lichen biomass during postfire succession in black spruce boreal forests. Can J For Res 39:2168-2179

Bradshaw CJA, Warkentin IG (2015) Global estimates of boreal forest carbon stocks and flux. Glob Plant Change 128:24-30

Brandt JP (2009) The extent of the north American boreal zone. Environ Rev 17: $101-161$

Burton JS, Kneeshaw DD, Coates KD (1999) Managing forest harvesting to maintain old growth in boreal and sub-boreal forests. For Chron 75:623-631

Cadieux P, Drapeau P (2017) Are old boreal forests a safe bet for the conservation of the avifauna associated with decayed wood in eastern Canada? For Ecol Manag 385:127-139

Carcaillet C, Bergeron Y, Richard PJH, Fréchette B, Gauthier S, Prairie YT (2001) Change of fire frequency in the eastern Canadian boreal forests during the Holocene: does vegetation composition or climate trigger the fire regime? J Ecol 89:930-946

Carleton TJ, Maycock PF (1978) Dynamics of the boreal forest south of James Bay. Can J Bot 56:1157-1173

Carleton TJ, Maycock PF (1980) Vegetation of the boreal forest south of James Bay: non-centered component analysis of the vascular flora. Can J Bot 69: 778-785

Certini G (2005) Effects of fire on properties of forest soils: a review. Oecologia 143:1-10

Charron I, Greene DF (2002) Post-wildfire seedbeds and tree establishment in the southern mixedwood boreal forest. Can J For Res 32:1607-1615

Cyr D, Bergeron Y, Gauthier S, Larouche AC (2005) Are the old-growth forests of the Clay Belt part of a fire-regulated mosaic? Can J For Res 35:65-73

Doblas-Miranda E, Work TT (2015) Localized effects of coarse woody material on soil oribatid communities diminish over 700 years of stand development in black-spruce-feathermoss forests. Forests 6:914-928

Drapeau P, Leduc A, Bergeron Y, Gauthier S, Savard J-PL (2003) Bird communities of old spruce-moss forests in the Clay Belt region: problems and solutions in forest management. For Chron 79:531-540

Esseen P-A, Ehnström B, Ericson L, Sjöberg K (1997) Boreal forests. Ecol Bull 46: $16-47$

Fenton N, Lecomte N, Légaré S, Bergeron Y (2005) Paludification in black spruce (Picea mariana) forests of eastern Canada: potential factors and management implications. For Ecol Manag 213:151-159

Fenton NJ, Bergeron Y (2007) Sphagnum community change after partial harvest in black spruce boreal forests. For Ecol Manag 242:24-33

Fenton NJ, Bergeron Y (2008) Does time or habitat make old-growth forests species rich? Bryophyte richness in boreal Picea mariana forests. Biol Conserv 141:1389-1399

Fenton NJ, Bergeron Y (2013) Stochastic processes dominate during boreal bryophyte community assembly. Ecology 94:1993-2006

Fenton NJ, Simard M, Bergeron Y (2009) Emulating natural disturbances: the role of silviculture in creating even-aged and complex structures in the black spruce boreal Forest of eastern North America. J For Res 14:258-267

Gauthier S, De Grandpré L, Bergeron Y (2000) Differences in forest composition in two boreal forest ecoregions of Quebec. J Veg Sci 11:781-790

Gauthier S, Nguyen T, Bergeron Y, Leduc A, Drapeau P, Grondin P (2004) Developing forest management strategies based on fire regimes in northwestern Quebec. In: Perera AH, Buse JL, Weber MG (eds) Emulating natural forest landscape disturbances: concepts and applications. Columbia University Press, New York, USA, pp 219-229

Gauthier S, Vaillancourt M-A, Leduc A, De Grandpré L, Kneeshaw DD, Morin H, Drapeau P, Bergeron Y (2008) Aménagement écosystémique en forêt boréale. Presses de l'Université du Québec, Québec, Canada

Giesler R, Peterson T, Högberg P (2002) Phosphorus limitation in boreal forests: effects of aluminum and iron accumulation in the humus layer. Ecosystems 5:300-314 
Girard F, Payette S, Gagnon R (2008) Rapid expansion of lichen woodlands within the closed-crown boreal forest zone over the last 50 years caused by stand disturbance in eastern Canada. J Biogeogr 35:529-537

Government of Canada (2017) The state of Canada's Forest, annual report. Canadian Forest Service, Natural Resources Canada, Government of Canada, Ottawa, Ontario, Canada, p 2017

Government of Quebec (2017) Sustainable Forest development act, A-18. Government of Quebec, Quebec, Canada, p 1

Gray DR, Régnière J, Boulet B (2000) Analysis and use of historical patterns of spruce budworm defoliation to forecast outbreak patterns in Quebec. For Ecol Manag 127:217-231

$>$ Greene DF, Macdonald SE, Cumming S, Swift L (2005) Seedbed variation from the interior through the edge of a large wildfire in Alberta. Can J For Res 35: 1640-1647

Greene DF, Macdonald SE, Haeussler S, Domenicano S, Noël J, Jayen K, Charron I, Gauthier S, Hunt S, Gielau ET, Bergeron Y, Swift L (2007) The reduction of organic-layer depth by wildfire in the north American boreal forest and its effect on tree recruitment by seed. Can J For Res 37:1012-1023

Groot A (2013) Fifteen-year results of black spruce uneven-aged silviculture in Ontario, Canada. Forestry 87:99-107

Groot AJ, Horton BJ (1994) Age and size structure of natural and second-growth peatland Picea mariana stands. Can J For Res 24:225-233

Harper K, Boudreault C, De Grandpré L, Drapeau P, Gauthier S, Bergeron Y (2003) Structure, composition, and diversity of old-growth black spruce boreal forest of the Clay Belt region in Quebec and Ontario. Environ Rev 11:S79-S98

Harper KA, Bergeron Y, Gauthier S, Drapeau P (2002) Post-fire development of canopy structure and composition in black spruce forests of Abitibi, Québec: a landscape scale study. Silva Fenn 36:249-263

Harvey B, Leduc A, Gauthier S, Bergeron Y (2002) Stand-landscape integration in natural disturbance-based management of the southern boreal forest. For Ecol Manage 155:369-385.

Hébert F, Thiffault N (2011) The biology of Canadian weeds. 146. Rhododendron groenlandicum (Oeder) Kron and Judd. Can J Plant Sci 91:725-738

Johnson DW, Curtis PS (2001) Effects of forest management on soil C and N storage: meta-analysis. For Ecol Manag 140:227-238

Johnson EA, van Wagner CE (1985) The theory and use of two fire history models. Can J For Res 15:214-220

Johnstone JF, Chapin FS III (2006) Effects of soil burn severity on post-fire tree recruitment in boreal forest. Ecosystems 9:14-31

Keenan RJ, Kimmins JP (1993) The ecological effects of clear-cutting. Environ Rev 1:121-144

Kishchuk BE, Thiffault E, Lorente M, Quideau S, Keddy T, Sidders D (2014) Decadal soil and stand response to fire, harvest, and salvage-logging disturbances in the western boreal mixedwood forest of Alberta. Canada Can J For Res 45: $141-152$

Kneeshaw D, Gauthier S (2003) Old growth in the boreal forest: a dynamic perspective at the stand and landscape level. Environ Rev 11:99-114

Laamrani A, Valeria O, Bergeron Y, Fenton NJ, Cheng LZ (2015) Distinguishing and mapping permanent and reversible paludified landscapes in Canadian black spruce forests. Geoderma 237-238:88-97

Lafleur B, Fenton NJ, Paré D, Simard M, Bergeron Y (2010b) Contrasting effects of season and method of harvest on soil properties and the growth of black spruce regeneration in the boreal forested peatlands of eastern Canada. Silva Fenn 44:799-813

Lafleur B, Paré D, Fenton NJ, Bergeron Y (2010a) Do harvest methods and soil type impact the regeneration and growth of black spruce stands in northwestern Quebec? Can J For Res 40:1843-1851

Lafleur B, Paré D, Fenton NJ, Bergeron Y (2011) Growth and nutrition of black spruce seedlings in response to disruption of Pleurozium and Sphagnum moss carpets. Plant Soil 345:141-153

Lafleur B, Renard S, Leroy C, Fenton NJ, Simard M, Gauthier S, Paré D, Leduc A, Thiffault N, Bergeron Y (2016) Silviculture to sustain productivity in black spruce paludified forests. For Ecol Manag 375:172-181

Lemprière TC, Kurz WA, Hogg EH, Schmoll C, Rampley GJ, Yemshanov D, McKenney DW, Gilsenan R, Beatch A, Blain D, Bhatti JS, Krcmar E (2013) Canadian boreal forests and climate change mitigation. Environ Rev 21: 293-321

Lavoie M, Harper K, Paré D, Bergeron Y (2007) Spatial pattern in the organic layer and tree growth: a case study from regenerating Picea mariana stands prone to paludification. J Veg Sci 18:213-222
Lavoie M, Paré D, Bergeron Y (2005a) Impact of global change and forest management on carbon sequestration in northern forested peatlands. Environ Rev 13:199-240

Lavoie M, Paré D, Fenton N, Groot A, Taylor K (2005b) Paludification and management of forested peatlands in Canada: a literature review. Environ Rev 13:21-50

Lecomte N, Bergeron Y (2005) Successional pathways on different surficial deposits in the coniferous boreal forest of the Quebec Clay Belt. Can J For Res 35:1984-1995

Lecomte N, Simard M, Bergeron Y (2006a) Effects of fire severity and initial tree composition on stand structural development in the coniferous boreal forest of northwestern Quebec, Canada. Ecoscience 13:152-163

Lecomte N, Simard M, Bergeron Y, Larouche A, Asnong H, Richard PJH (2005) Effects of fire severity and initial tree composition on understorey vegetation dynamics in a boreal landscape inferred from chronosequence and paleoecological data. J Veg Sci 16:665-674

Lecomte N, Simard M, Fenton N, Bergeron Y (2006b) Fire severity and long-term ecosystem biomass dynamics in coniferous boreal forests of eastern Canada. Ecosystems 9:1215-1230

Lorente M, Parsons WFJ, Bradley RL, Munson AD (2012) Soil and plant legacies associated with harvest trails in boreal black spruce forests. For Ecol Manag 269:168-176

Mallik AU (1993) Ecology of a forest weed of Newfoundland: vegetative regeneration strategy of Kalmia angustifolia. Can J Bot 71:161-166

Mallik AU (2003) Conifer regeneration problems in boreal and temperate forests with ericaceous understory: role of disturbance, seedbed limitation, and keystone species change. Crit Rev Plant Sci 22:341-366

Martin JL, Gower ST (2006) Boreal mixedwood tree growth on contrasting soils and disturbance types. Can J For Res 36:986-995

Martin M, Fenton NJ, Morin H (2018) Structural diversity and dynamics of boreal old growth forests case study in eastern Canada. For Ecol Manag 422:125136

Maynard DG, Paré D, Thiffault E, Lafleur B, Hogg KE, Kishchuk B (2014) How do natural disturbances and human activities affect soils on tree nutrition and growth in the Canadian boreal forest? Environ Rev 22:161-178

McRae DJ, Duchesne LC, Freedman B, Lynham TJ, Woodley S (2001) Comparisons between wildfire and forest harvesting and their implications in forest management. Environ Rev 9:223-260

Morin H, Laprise D, Simard A-A, Amouch S (2009) Spruce budworm outbreak regimes in eastern North America. In: Gauthier S, Vaillancourt M-A, Leduc A, De Grandpré L, Kneeshaw DD, Morin H, Drapeau P, Bergeron Y (eds) Ecosystem management in the boreal forest. Les Presses de I'Université du Québec. Québec, Canada, pp 155-182

Moroni MT, Morris DM, Shaw C, Stokland JN, Harmon ME, Fenton NJ, Merganičová K, Merganič J, Okabe K, Hagemann U (2015) Buried wood: a common yet poorly documented form of deadwood. Ecosystems 18:605-628

Nave LE, Vance ED, Swanston CW, Curtis PW (2011) Fire effects on temperate forest soil C and N storage. Ecol Appl 21:1189-1201

Neff JC, Harden JW, Gleixner G (2005) Fire effects on soil organic matter content, composition, and nutrients in boreal interior Alaska. Can J For Res 35:2178-2187

Nguyen-Xuan T, Bergeron Y, Simard D, Fyles JW, Paré D (2000) The importance of forest floor disturbance in the early regeneration patterns of the boreal forest of western and Central Quebec: a wildfire versus logging comparison. Can J For Res 30:1353-1364

Paradis S, Work TT (2011) Partial cutting does not maintain spider assemblages within the observed range of natural variability in eastern Canadian black spruce forests. For Ecol Manag 262:2079-2093

Payette S, Rochefort L (2001) Écologie des tourbières du Québec-Labrador. Presses de I'Université Laval. In: Ste-Foy. Québec, Canada

Preston CM, Simard M, Bergeron Y, Bernard GM, Wasylishen RE (2017) Charcoal in organic horizon and surface mineral soil in a boreal forest fire chronosequence of western Quebec: stocks, depth distribution, chemical properties and a synthesis of related studies. Front Earth Sci 5:98

Renard SM, Gauthier S, Fenton NJ, Lafleur B, Bergeron Y (2016) Prescribed burning after clearcut limits paludification in black spruce boreal forest. For Ecol Manag 359:147-155

Rowe JS (1983) Concepts of fire effects on plant individuals and species. In: Wein RW, MacLean DA (eds) The role of fire in northern circumpolar ecosystems. Wiley \& Sons Itd, pp 135-154

Ruel J-C (1995) Understanding windthrow: Silvicultural implications. For Chron 71 434-445 
Seymour RS, Hunter ML Jr (1999) Principles of ecological forestry. In: Hunter ML Jr (ed) Maintaining biodiversity in Forest ecosystems. Cambridge University Press, Cambridge, UK, pp 22-61

Siitonen J (2001) Forest management, coarse woody debris and saproxylic organisms: Fennoscandian boreal forests as an example. Ecol Bull 49:1-31

Simard D, Fyles JW, Paré D, Nguyen T (2001) Impacts of cleatcut harvesting and wildfire on soil nutrient status in the Quebec boreal forest. Can J Soil Sci 81 229-237

Simard M, Lecomte N, Bergeron Y, Bernier PY, Paré D (2007) Forest productivity decline caused by successional paludification of boreal soils. Ecol Appl 17: 1619-1637

Simard M, Lecomte N, Bergeron Y, Bernier PY, Paré D (2009) Ecosystem management of Québec's northern Clay Belt spruce forest: managing the forest and especially the soils. In: Gauthier S, Vaillancourt M-A, Leduc A, De Grandpré L, Kneeshaw DD, Morin H, Drapeau P, Bergeron Y (eds) Ecosystem management in the boreal forest. In. Ecosystem management in the boreal forest. Les Presses de l'Université du Québec, Québec, Canada, pp 257-286

Smithwick EAH, Turner MG, Mack MC, Chapin FS III (2005) Postfire soil N cycling in northern conifer forests affected by severe, stand-replacing wildfires. Ecosystems 8:163-181

Tamm C (1991) Nitrogen in terrestrial ecosystems: questions of productivity, vegetational changes, and ecosystem stability. Springer-Verlag, Heidelberg, Germany

Taylor SL, MacLean DA (2009) Legacy of insect defoliators: increased wind-related mortality two decades after a spruce budworm outbreak. For Sci 55:256-267

Thiffault E, Bélanger N, Paré D, Munson AD (2007) How do forest harvesting methods compare with wildfire? A case study of soil chemistry and tree nutrition in the boreal forest. Can J For Res 37:1658-1668

Thiffault N, Fenton N, Munson AD, Hébert F, Fournier RA, Valeria O, Bradley RL, Bergeron Y, Grondin P, Paré D, Joanisse G (2013) Managing understory vegetation for maintaining productivity in black spruce forests: a synthesis within a multi-scale research model. Forests 4:613-631

Wan S, Hui D, Luo Y (2001) Fire effects on nitrogen pools and dynamics in terrestrial ecosystems: a meta-analysis. Ecol Appl 11:1349-1365

Writh C, Gleixner G, Heimann M (2009) Old-growth forests. Function, fate, and value. Springer, NY

Zhang Y, Biswas A (2017) The effects of Forest fire on soil organic matter and nutrients in boreal forests of North America: a review. In: Rakshit A, Abhilash PC, Singh HB, Ghosh S (eds) Adaptive soil management from theory to practices. Springer, NY, pp 465-476

\section{Submit your manuscript to a SpringerOpen ${ }^{\circ}$ journal and benefit from:}

- Convenient online submission

- Rigorous peer review

- Open access: articles freely available online

- High visibility within the field

- Retaining the copyright to your article

Submit your next manuscript at $\gg$ springeropen.com 